\title{
Evaluation of Seasonal Changes in Temperature and Precipitation for Iran Five Provincial Centres during 1960-2017
}

\author{
Akram Hedayati-Dezfuli ${ }^{1}$, Farahnaz Fazel-Rastgar ${ }^{2 *}$ \\ ${ }^{1}$ Atmospheric Science and Meteorological Research Centre, Tehran, Iran \\ ${ }^{2}$ York University, Toronto, Ontario, Canada \\ Email: ^ffazelrastgar@gmail.com
}

How to cite this paper: Hedayati-Dezfuli, A., \& Fazel-Rastgar, F. (2020). Evaluation of Seasonal Changes in Temperature and Precipitation for Iran Five Provincial Centres during 1960-2017. Journal of Geoscience and Environment Protection, 8, 77-93.

https://doi.org/10.4236/gep.2020.812005

Received: November 4, 2020

Accepted: December 13, 2020

Published: December 16, 2020

Copyright $\odot 2020$ by author(s) and Scientific Research Publishing Inc. This work is licensed under the Creative Commons Attribution International License (CC BY 4.0).

http://creativecommons.org/licenses/by/4.0/

\begin{abstract}
Climate change is one of the key challenges of our era and it is a threat to sustainable development. Global warming has many meteorological consequences including rising air temperatures across the world. Undoubtedly, human activity has been one of the key factors to global warming followed by increased greenhouse gas emissions which will exacerbate changes in the Earth's climate variables. So, any research work related to the climate around the world including Iran due to climate change may cause to better understand the cause and effect and make a better adaptation. This study investigates the regional warming in five meteorological stations in central provinces of Iran, based on seasonal changes in precipitation and temperatures over the period of 1960-2017 (study period). The seasonal drought severity based on Palmer index during 1960-2005 was used to monitor the drought intensity in the study areas which are in drought risk situation. The classification of drought severity using Palmer index shows the severe drought intensity in Arak, Qom, Semnan, Tehran and Isfahan respectively in all four seasons, especially during fall and summer. The slight changes in the coefficients of seasonal maximum, minimum and mean temperatures have been resulted. According to these results, the highest maximum (minimum) temperature rise has been calculated for Qom (Tehran) station during spring and winter (fall) seasons $\sim 0.44^{\circ} \mathrm{C}\left(\sim 0.67^{\circ} \mathrm{C}\right)$ in a decade during 1960-2017. However, the highest decrease in precipitation over Arak station has been calculated $\sim 13.8$ $\mathrm{mm}$ in a decade in winter during study period.
\end{abstract}

\section{Keywords}

Drought, Climate Change, Regional Warming, Low Rainfall 


\section{Introduction}

Drought is a creeping and silent phenomenon that results from a shortage of rainfall over a long period, usually in one or several months or seasons. Therefore, this phenomenon has a hidden nature, and the duration of its long-term effects and its effects in various sectors, such as agriculture, social, economic, environmental, etc., are very widespread and gradually appear. Human life has been exposed to a variety of natural hazards throughout history and throughout the world as part of these hazards and accidents caused by climatic processes that depend on the geographical location. However, anomalies and fluctuations in the meteorological parameters trends such as precipitation and temperature are natural features of the atmospheric circulation (Institute of Meteorology 2008). These such anomalies are severe in many parts of the world and may disrupt natural ecosystems (CCSP, 2008; Settele, 2014). Droughts are a clear indication of the fluctuations that affect many arid and semi-arid regions of the world at different intensities every few years. The need for water in the future will increase with increasing population and social changes along with the changes in people's living standards. So, the increase in water demand in dry and low water periods will be much more critical in the future. Since all climatic regions of the world can be at risk of drought, so this phenomenon could occur in any climatic region. But the characteristics of drought vary in different climates. Unlike drought, which is a permanent and inherent feature of some parts of the world, water shortage is a temporary phenomenon known as lack of water in a region relative to its long-term average. The main cause of drought is the lack of rainfall and its variants are involved with meteorological, agricultural, hydrological and socio-economic kinds. The decrease in precipitation over a period of time is considered to be meteorological drought, the origin of which is irregularities in the global pattern of large-scale atmospheric circulation (Institute of Meteorology, 2010). In other words, drought is a prolonged period of shortage of rainfall that can damage crops and reduce yield. From the point of view of the World Meteorological Organization, an abnormally dry weather period is characterized by a very wide range, a prolonged decline of more than one month, and below the specified precipitation threshold (WMO, 2015).

In recent decades with the population and industry growth, agricultural development, livestock development, human lifestyles changes and more have exacerbated the effects of drought in different parts of Iran. Drought in developed and developing countries, the vulnerability of all societies and the macroeconomic and social impacts of this disaster have made it a matter of greater concern for experts. Drought vulnerability based on frequency, the severity of the spatial level is defined as the degree of a population vulnerability or activity to the effects of the drought. In general, a drought risk assessment will have a crucial role in the development of the country's macro program planning, sustainable development, conservation of natural resources and successful human interaction with nature. 
The monitoring of the yearly precipitation averages in most parts of Iran during past decades has been reduced and they have increased the severity of drought risk in most parts of Iran such as the central part. Precipitations less than $80 \%$ of normal could be considered as the drought risk in Iran. Also, the total precipitation in the central regions of Iran decreases to zero during the drought years.

\section{Research Background in Iran and Some Other Countries}

Sayari et al. (2012) assessed the climate change impacts on drought conditions by using the drought indices in the northeast of Iran. They concluded that there was a slight increase in the rainfall and the minimum and maximum temperatures also were increased within the 1961-1990 period. Drought periods in the northeast part of Iran (city of Mashhad) for a period of 32 years (1968-1999) were investigated by Sanainejad et al. (2003). They examined the standardized precipitation index (SPI) for their research. Ansari et al. (2010) by using SPI (Standardized Precipitation Index) and the Standardized Evapotranspiration Index monitored the drought for a monthly scale of 1 - 3 in Mashhad station in the northeast of Iran. Hejazi Zadeh et al. (2014) analysed the precipitation at Kerman station using statistical methods and drought indices. For this purpose, they analyzed the fluctuations of the seasonal precipitation data of Kerman synoptic station over a 50-year period and examined the trend of precipitation changes. Next, Mann-Kendall nonparametric statistics were used to test the significance of the trend of seasonal variations and fluctuations. Also, by using the dry drought indices, the dry, normal and humid periods of the season were determined.

Palmer (1965) surveyed drought in nine parts of the United States and identified PDSI as an efficient indicator in describing droughts. He considered equations for index calculations that can be used to obtain good results by applying the calibration condition performed in different regions.

Due to drought trend increasing, there have been many other studies around the world, for example, McKee et al. (1995) by comparing the correlation coefficients between the two standard precipitation indices and the Palmer index on multiple time scales. They concluded that two indices have the highest correlation on a near-12-month time scale, at which this correlation coefficient is close to 0.9. This is the lowest correlation to a 24 month time scale. Smith et al. (1996) studied the drought in central part of Europe. Drought in the Mediterranean region was investigated by Watson et al. (1997). Hayes et al. (1999) assessed the drought in the state of Oklahoma and Texas using the SPI and Palmer Index. Their results showed that the SPI can detect the onset of drought and its progress. These researchers described the index as a good indicator of drought alert. Also, Brunetti et al. (2002) studied drought in Italy. Smith (2000) stated that the deciles index (DI) method is relatively simple to calculate and requires fewer data and assumptions than the Palmer dryness index. The deciles index was de- 
fined by Gibbs \& Maher (1967). Lawrimore et al. (2002) studied drought across North America. Spinoni et al. (2014) used 50-year daily precipitation and temperature statistics from 1961 to 2010 to analyse the drought events in the Carpathian region between 1961 and 2010. Four drought indices of SPI, SPEI (Standardised Precipitation-Evapotranspiration Index), RDI (Reconnaissance Drought Index) and PaDI (Palfai Drought Index) were calculated in cells 0.1 to 0.1 degree. The SPI, SPEI and RDI indices were estimated at 3, 6, and 12 months, while the PADI index was calculated annually. A list of droughts based on matching drought indices was provided and a case study was conducted on three droughts cases during 1990, 2000 and 2003. The result of different climate models projected significant temperature and precipitation changes due to global warming which will cause to occur to drought frequency was studied by Kebat et al. (2002) and Li et al. (2009). Drought indices were compared at both spatial and temporal scales. The results showed that the SPI, SPEI and RDI indices were highly comparable especially in the 12-month cumulative period. Mondol et al. (2016) assessed the drought Index in Bangladesh. Bayissa et al. (2018) compared the six Drought Indices related to historical drought for the Upper Blue Nile Basin in Ethiopia.

\section{Materials and Methods}

The purpose of this study is to investigate the drought and regional warming trends with a basic study of the regional climate change in five central cities of Iran, considering linear changes in temperature and precipitation parameters through the time series analysis. Then the NCEP (National Centres for Environmental Prediction) data including the Palmer Drought Severity Index (PDSI, Palmer, 1965) was analysed for different seasons during 1960-2005 for the study aea. This may give a good idea from the standpoint of classifying different degrees of drought in the region.

\section{Palmer Drought Severity Index (PDSI)}

This index is based on the equation of soil water balance and the required input data are monthly rainfall and air temperature. The moisture storage is examined by dividing the soil into two layers and it is assumed that $25 \mathrm{~mm}$ of water can be stored in the surface layer. The underlying layer has a water capacity that depends on soil properties. Unless all available moisture reaches the surface layer, moisture cannot be removed from the bottom layer of soil. Potential evapotranspiration (PE) is generally calculated by the method of Torrent White. The basic data required for the model include monthly rainfall in $\mathrm{mm}$, mean monthly temperature in degrees Celsius, and soil moisture content in $\mathrm{mm}$, which is defined as the maximum rainfall height that, if it falls on soils with specified properties, is excess rainfall and becomes runoff or infiltration.

The Palmer index for dry and wet periods are categorized and shown in Table 1. 


\section{Geographical Landscape of the Study Area}

Figure 1 shows a geographical map of the area examined with the geomorphologic profile of the wider region. The selected stations present in the map. In this study, the monthly data including precipitation and temperature parameters (mean, maximum and minimum) of five synoptic stations in the central part of Iran (Tehran, Arak, Qom, Semnan and Isfahan) from Iran meteorological organization were obtained. The length of the statistical period for these data is 1960-2017. The geographical and climatic characteristics of the selected stations are presented in Table 2.

Table 1. Classification of drought severity by palmer index.

\begin{tabular}{ccc}
\hline Code & Class & PDSI range \\
\hline D4 & extreme drought & PDSI $<-4$ \\
D3 & severe drought & $-4<$ PDSI $\leq-3$ \\
D2 & moderate drought & $-3<$ PDSI $\leq-2$ \\
D1 & mild drought & $-2<$ PDSI $\leq-1$ \\
N & near normal & $-1<$ PDSI $\leq 1$ \\
W1 & mild wet & $1 \leq$ PDSI $<2$ \\
W2 & moderate wet & $2 \leq$ PDSI $<3$ \\
W3 & very wet & $3 \leq$ PDS $<4$ \\
W4 & extremely wet & $4 \leq$ PDSI \\
\hline
\end{tabular}

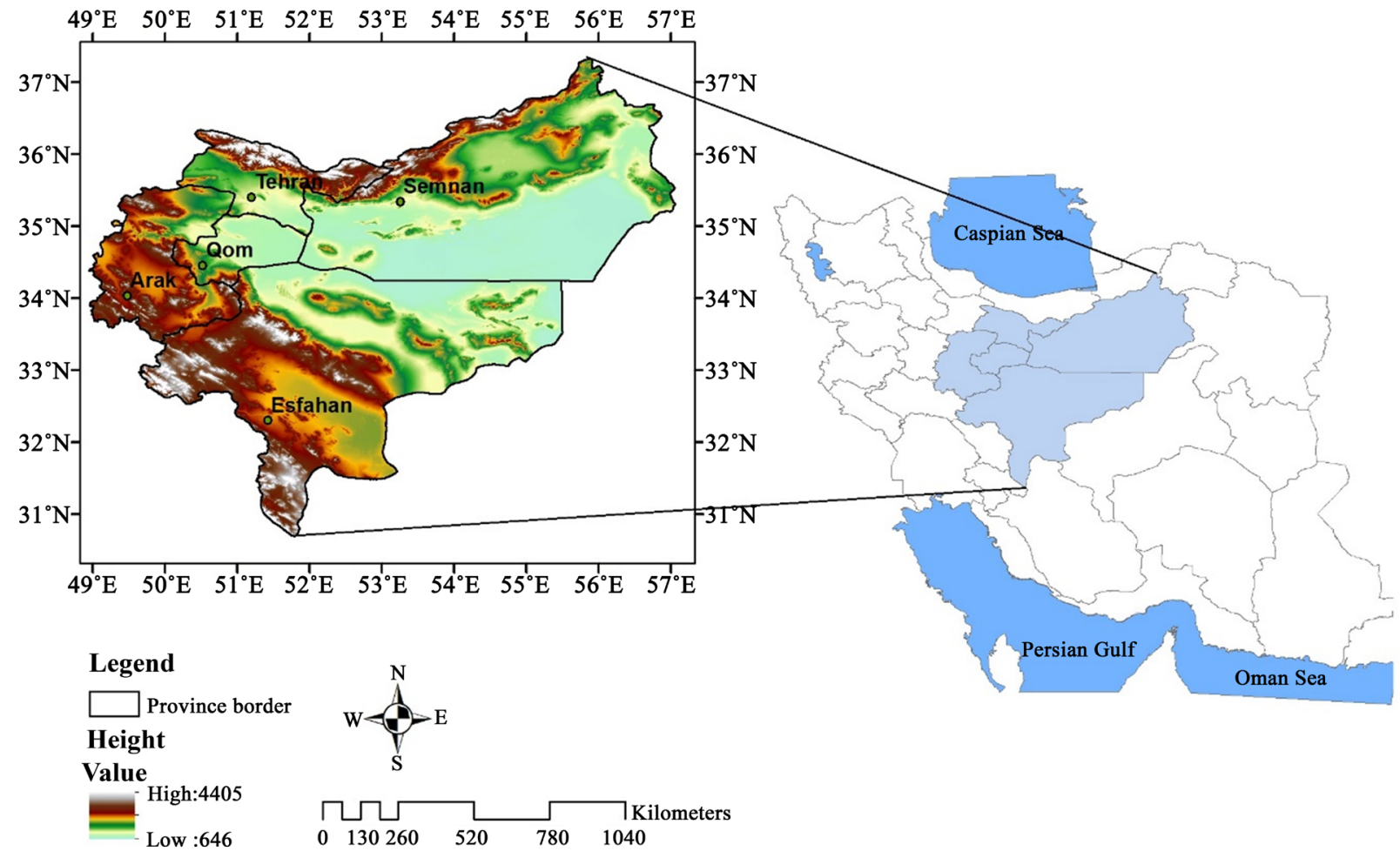

Figure 1. Geographical location of the studied stations in Iran. 


\section{Seasonal Palmer Index Values}

As, it mentioned earlier in data and methods section, here, by analysing the Palmer Index using NCEP (Kalnay et al., 1996) available datasets, we attempt to estimate the severity of the drought and classify it seasonally during the period of 1960-2005. Figures 2-5 show the seasonal plots including winter, spring, summer and fall for palmer index over the area of study during 1960-2005 respectively.

During winter season as Figure 2 shows, Arak showed the highest drought intensity with the index value less than -1.2 and then Qom, Isfahan, Semnan and Tehran experienced the highest drought intensity in winter during the studied statistical period (1960-2005). The intensity of this drought is mild or close to normal with respect to the values shown in Table 1 . During spring, based on

Table 2. Mean geographic and climatic characteristics of the stations under study.

\begin{tabular}{cccccc}
\hline Station & $\begin{array}{c}\text { Latitude } \\
(\mathrm{D})\end{array}$ & $\begin{array}{c}\text { Longitude } \\
(\mathrm{D})\end{array}$ & $\begin{array}{c}\text { Height } \\
(\mathrm{m})\end{array}$ & $\begin{array}{c}\text { Mean yearly precipitation } \\
(1990-2017) \text { in millimeter }\end{array}$ & $\begin{array}{c}\text { Mean yearly temperature } \\
(1990-2017) \text { in Celsius }\end{array}$ \\
\hline Tehran & $35.41 \mathrm{~N}$ & $51.19 \mathrm{E}$ & 1191 & 230 & 18 \\
Arak & $34.04 \mathrm{~N}$ & $49.47 \mathrm{E}$ & 1702 & 300 & 14 \\
Qom & $34.46 \mathrm{~N}$ & $50.52 \mathrm{E}$ & 879 & 139 & 19.4 \\
Semnan & $35.35 \mathrm{~N}$ & $53.25 \mathrm{E}$ & 1127 & 134 & 17 \\
Isfahan & $32.31 \mathrm{~N}$ & $51.42 \mathrm{E}$ & 1551 & 133 & \\
\hline
\end{tabular}

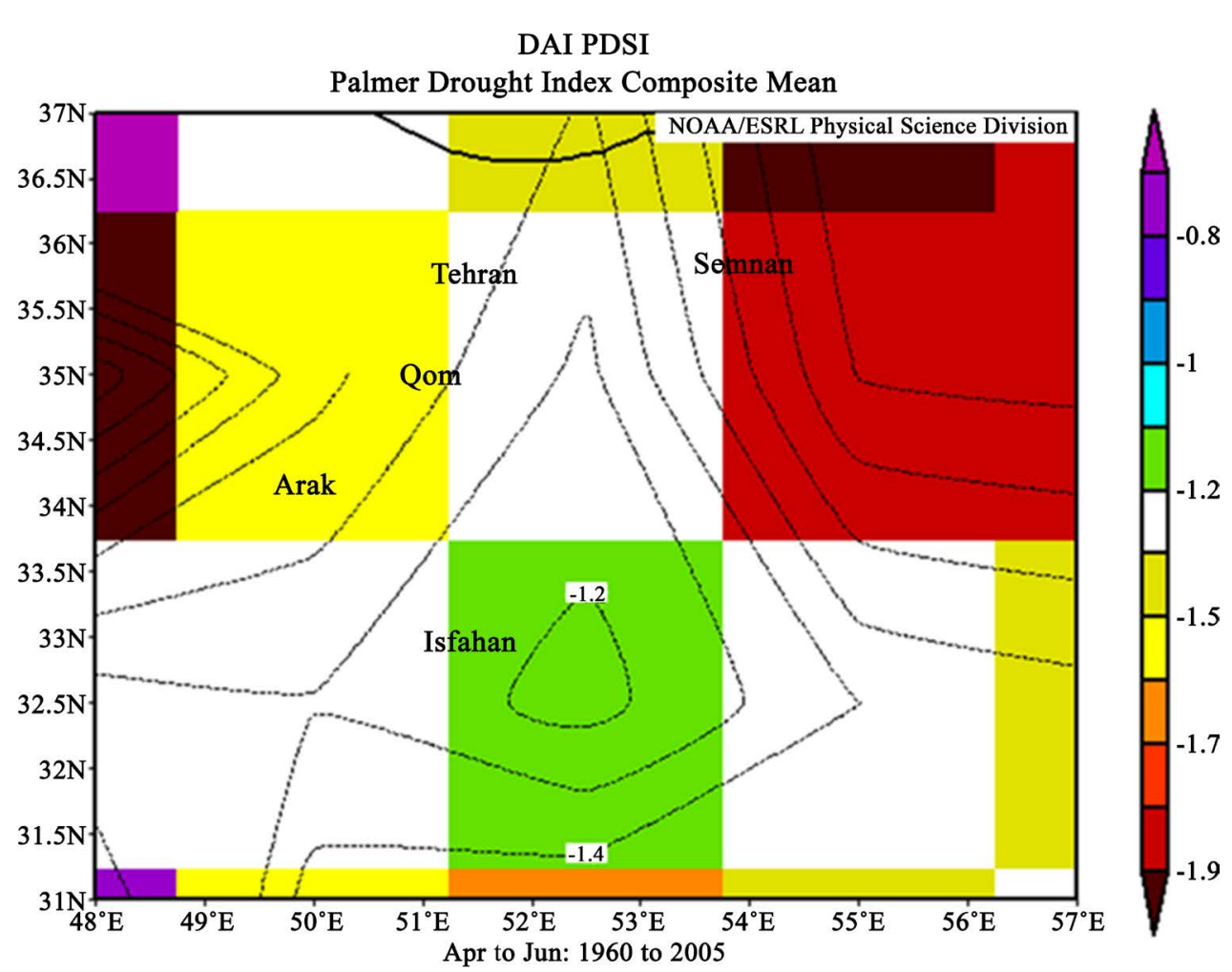

Figure 2. Mean Palmer Index in the study area for spring season during 1960-2005. Source from http://www.esrl.noaa.gov/psd/. 


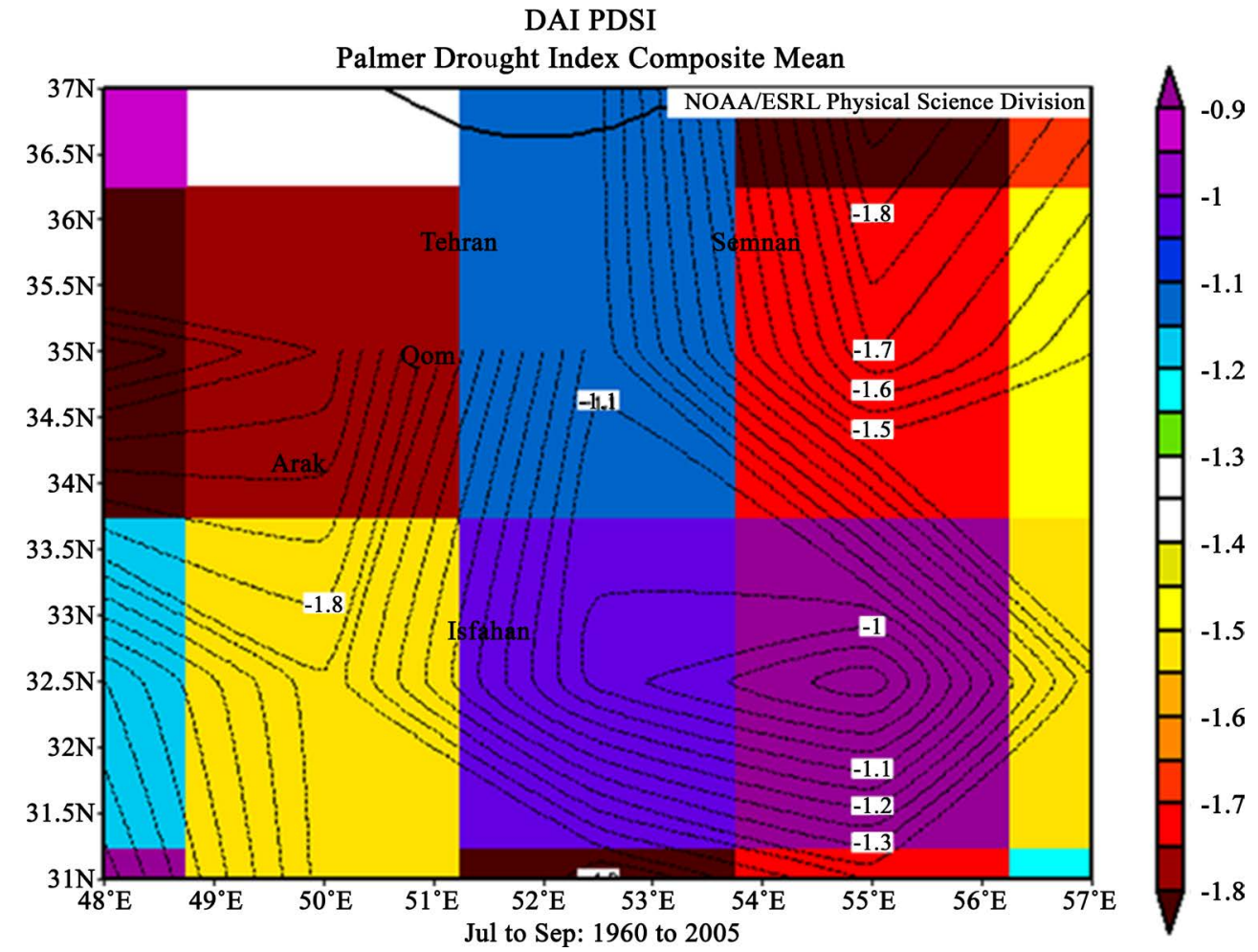

Figure 3. Mean Palmer Index in the study area for summer season during 1960-2005. Source from http://www.esrl.noaa.gov/psd/.

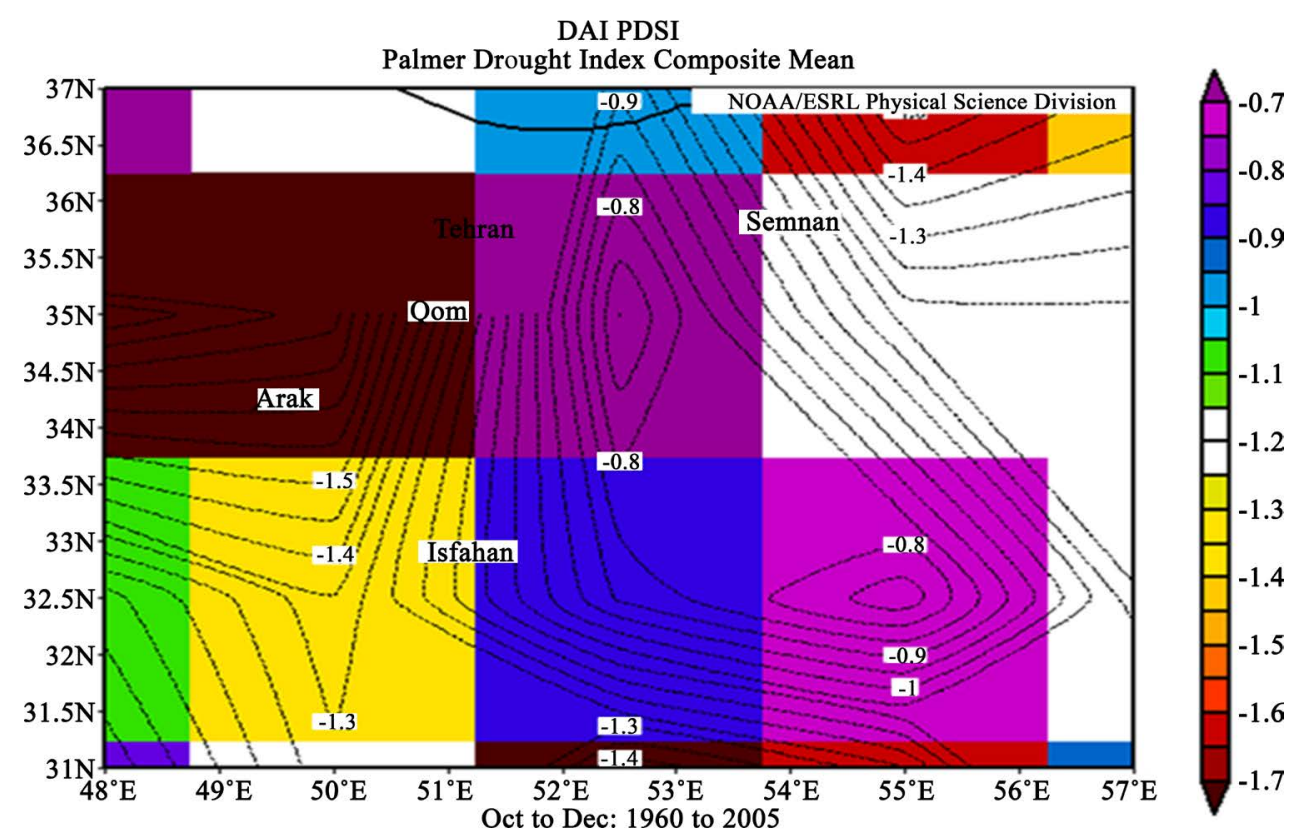

Figure 4. Mean Palmer Index in the study area for fall season during 1960-2005. Source from http://www.esrl.noaa.gov/psd/.

Figure 3, the city of Semnan with an intensity of -1.7 showed the highest intensity and then Arak, Qom, Tehran and Isfahan had a mild drought. For summer (Figure 4) Arak experienced moderate drought (palmer index of -2.0) and 
Qom, Semnan, Tehran and Isfahan showed a mild drought respectively. During fall, Arak and Qom showed the most drought during this season (palmer index of -2.0) and Isfahan, Semnan and Tehran had mild drought (Figure 5). Thus, Arak and Qom appear to have had the most drought intensity in all three seasons except spring, after Semnan. In Figures 2-5, the horizontal and vertical axes are longitude and latitude in degrees. The classification of drought in the selected stations in the central provinces of Iran for the statistical period (1960-2005) is summarized in Table 3.

\section{DAI PDSI}

Palmer Drought Index Composite Mean

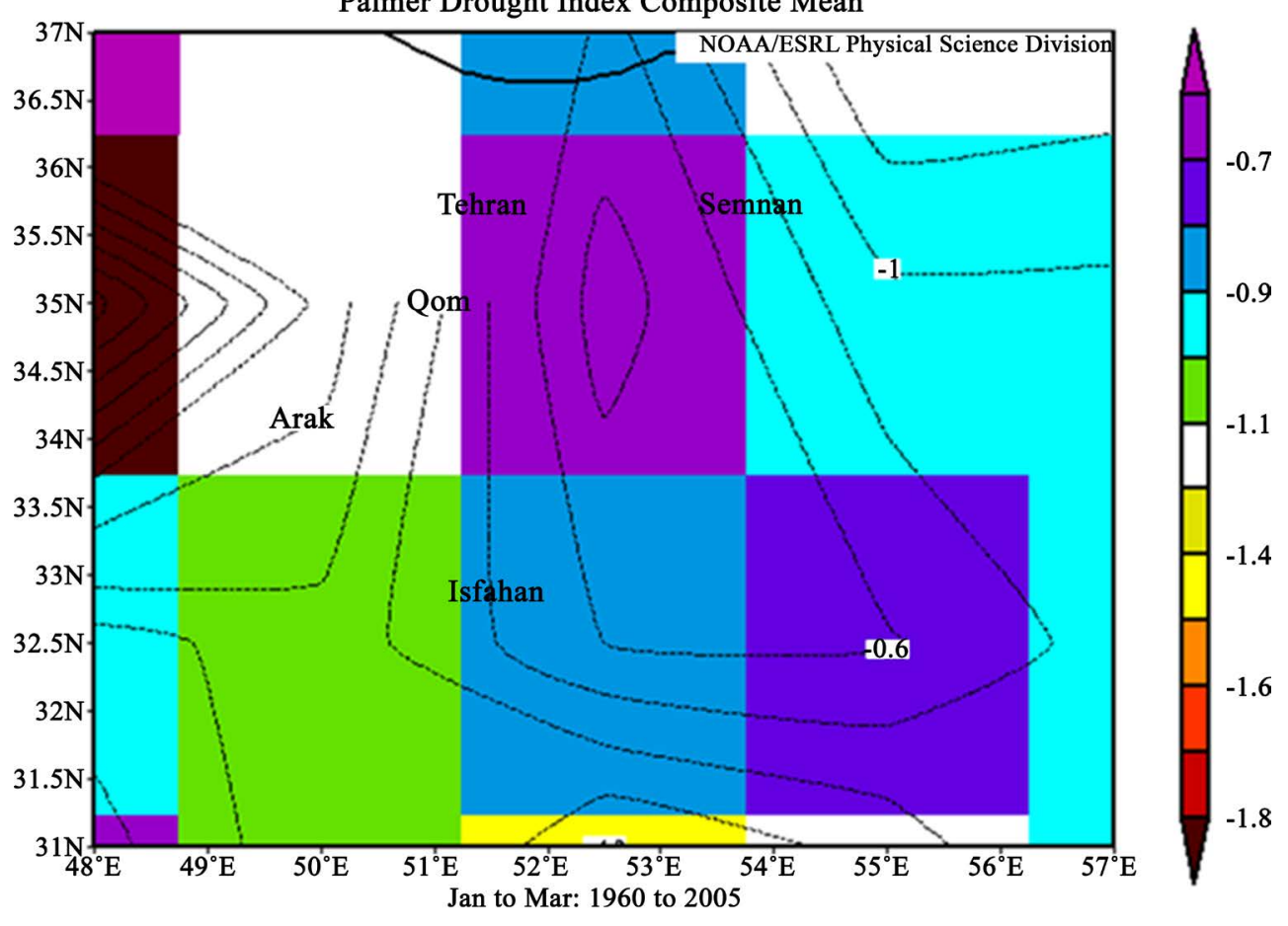

Figure 5. Mean Palmer Index in the study area for winter season during 1960-2005. Source from http://www.esrl.noaa.gov/psd/.

Table 3. Seasonal classification of drought severity at selected stations based on Palmer index (1960-2005).

\begin{tabular}{ccccc}
\hline Drought class & Spring & Summer & Fall & Winter \\
\hline \multirow{2}{*}{ Moderate } & & Arak & Arak, & \\
& & & Qom & \\
& Arak, & Qom, & Tehran, & \\
Qom, & Tehran, & Semnan, & Arak, \\
Mild & Tehran, Semnan, & Semnan, & Isfahan & Qom \\
& Isfahan & Isfahan & & \\
& & & & Tehran, \\
& & & & Semnan, \\
& & & Isfahan \\
\hline
\end{tabular}




\section{Seasonal Trends in Temperatures and Precipitation}

Here, to study the possible warming trends in the central region of Iran at selected stations, we have calculated the linear correlation for the mean, minimum and the maximum temperatures and mean precipitation for four seasons over the period of 1960-2017. Here, the figures for the spectral analysis of seasonal mean temperatures and mean precipitation are only shown. However, the results for maximum and minimum temperatures along with mean values are also summarized in Tables 4-7. The seasonal trends and significant probabilities (\%) for mean temperatures of selected stations (1960-2017) have brought in Table 8. Figures 6-15 show all trends for mentioned parameters. It is noted that the city of Qom has some years in the data gap during the study period.

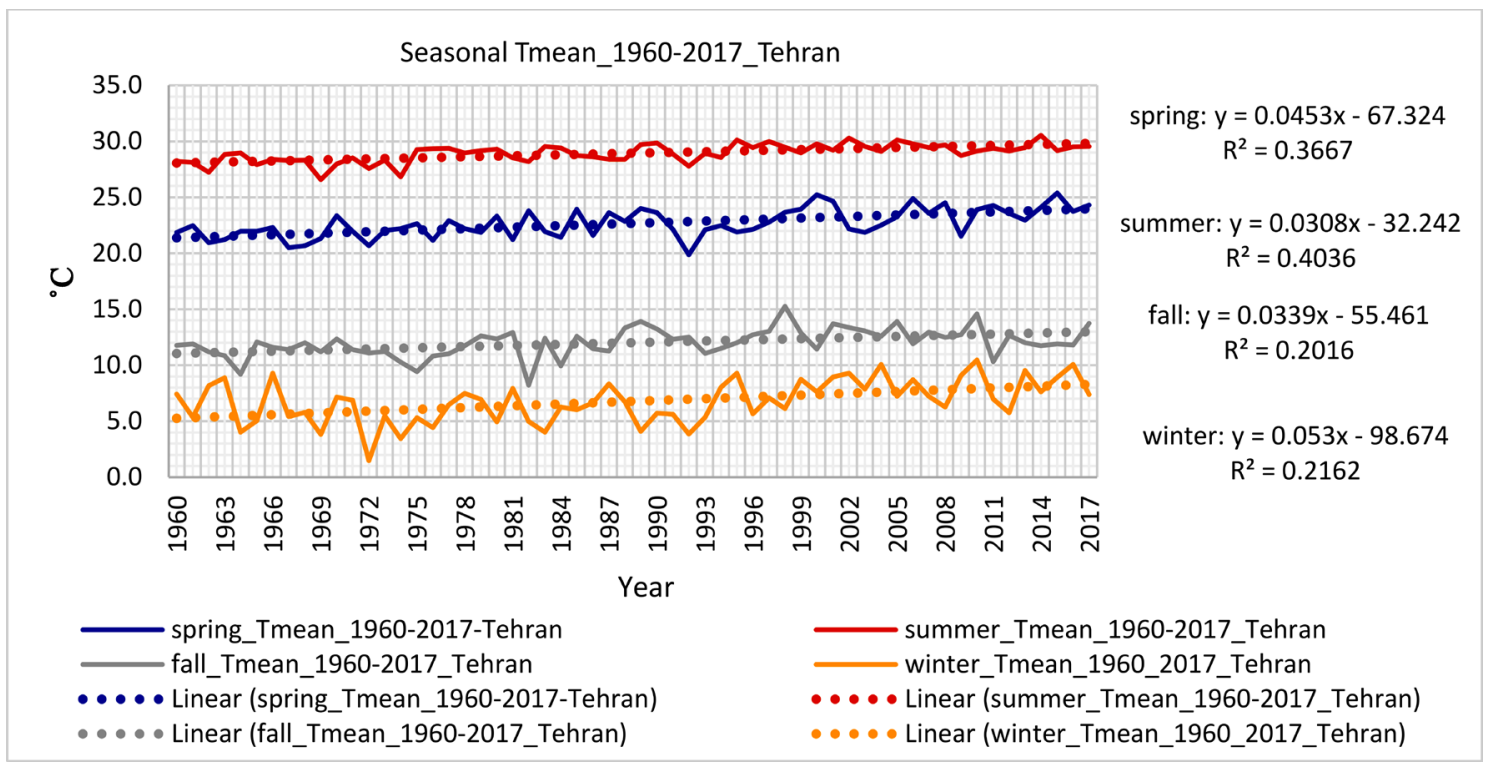

Figure 6. Seasonal mean temperature changes in Tehran (1960-2017).

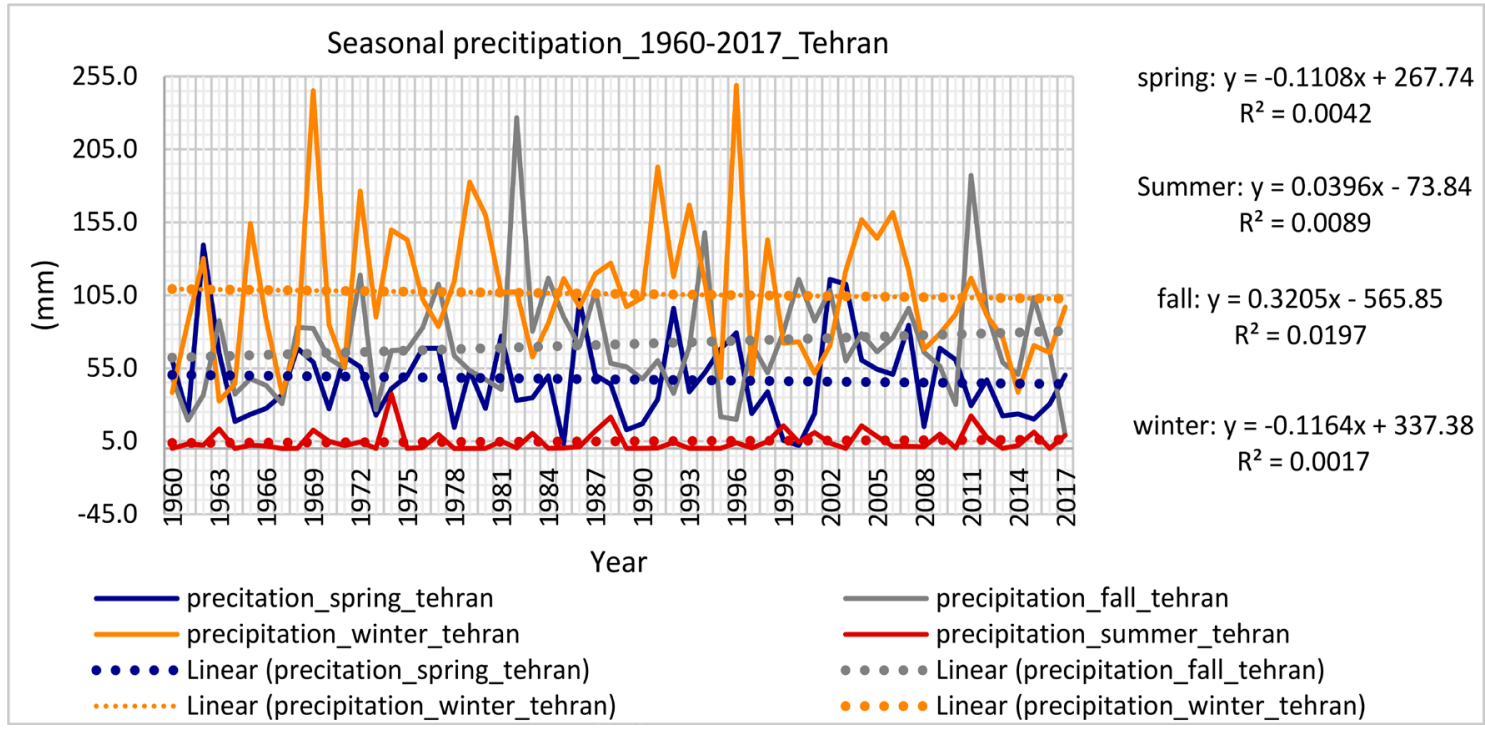

Figure 7. Seasonal mean precipitation changes in Tehran (1960-2017). 


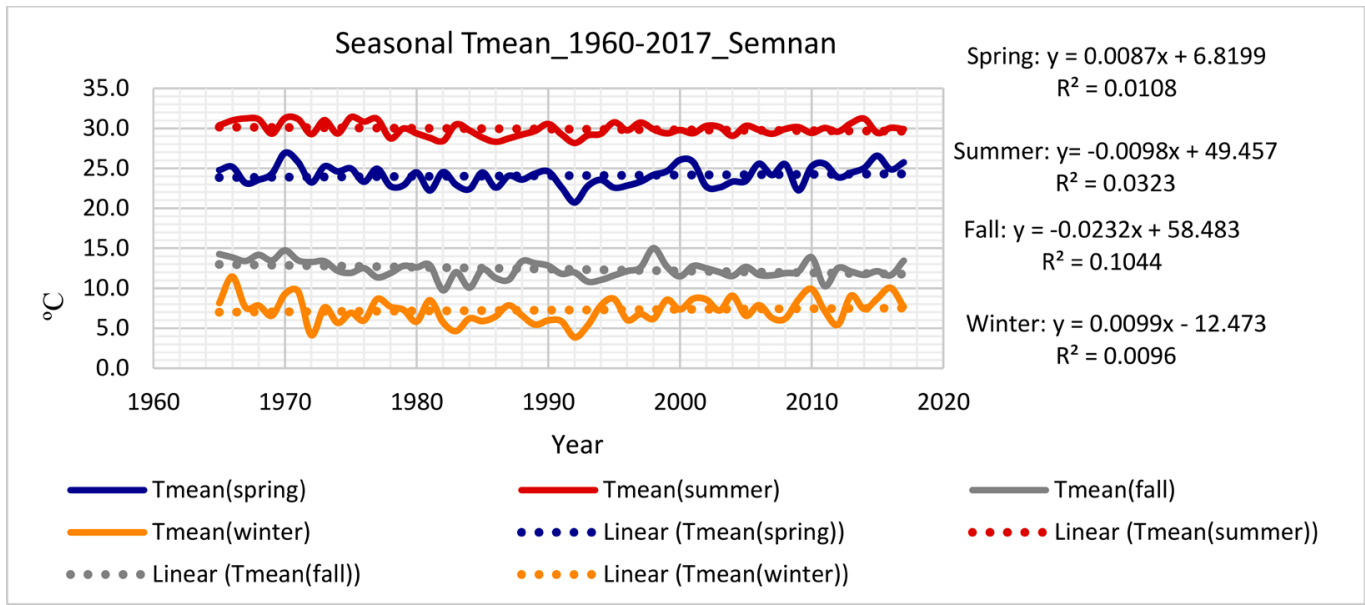

Figure 8. Seasonal mean temperature changes in Semnan (1960-2017).

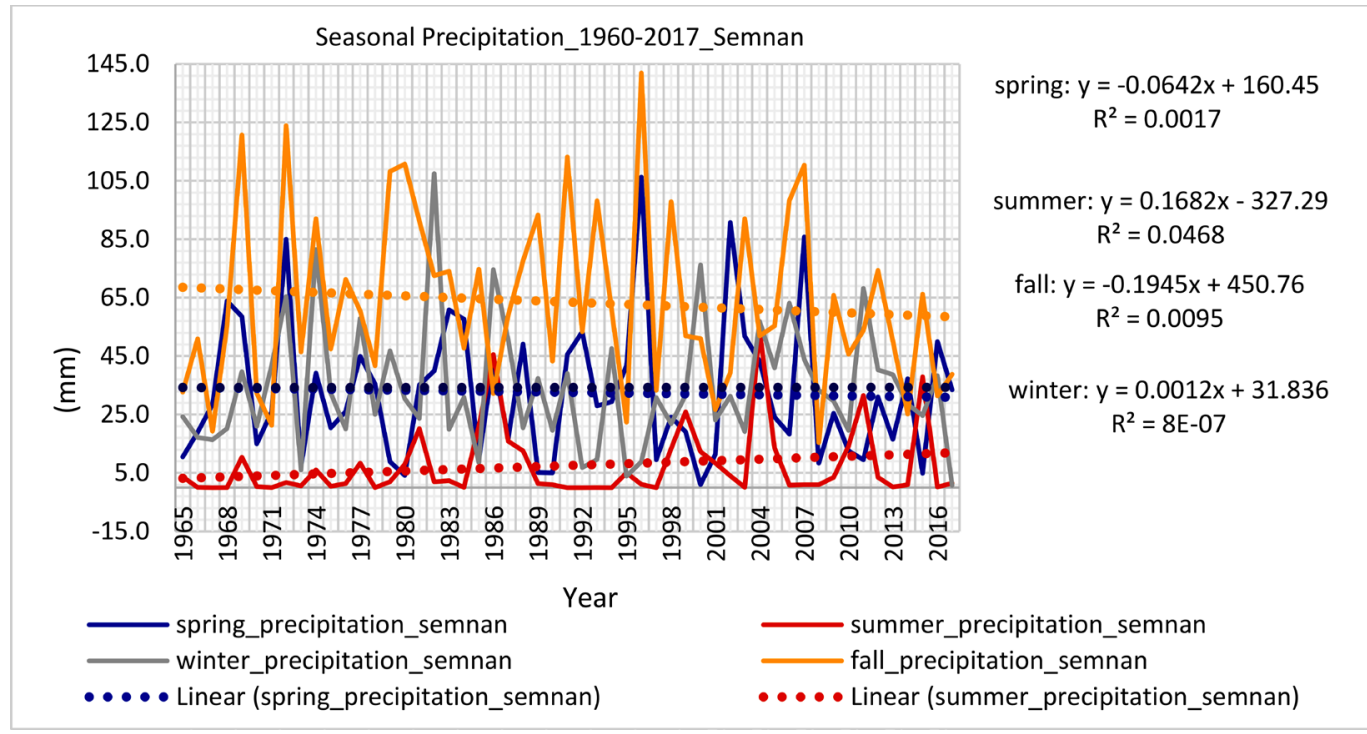

Figure 9. Seasonal mean precipitation changes in Semnan (1960-2017).

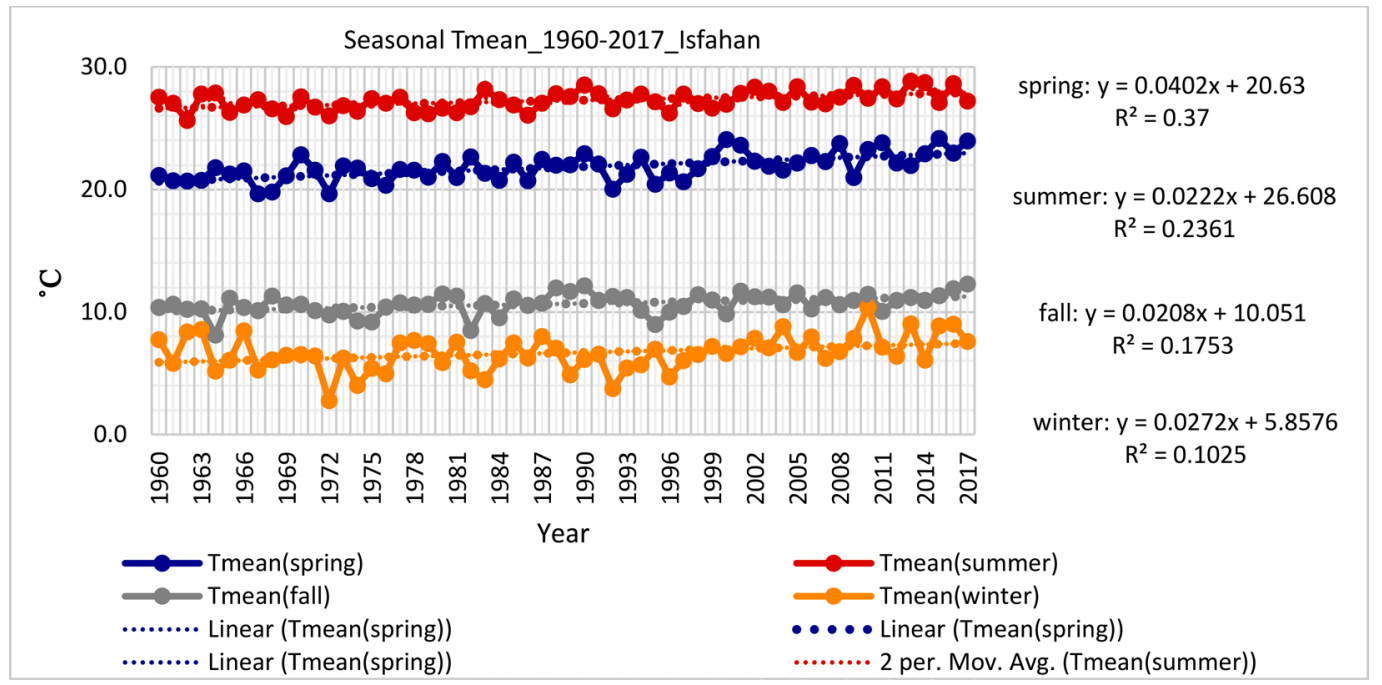

Figure 10. Seasonal mean temperature changes in Isfahan (1960-2017). 


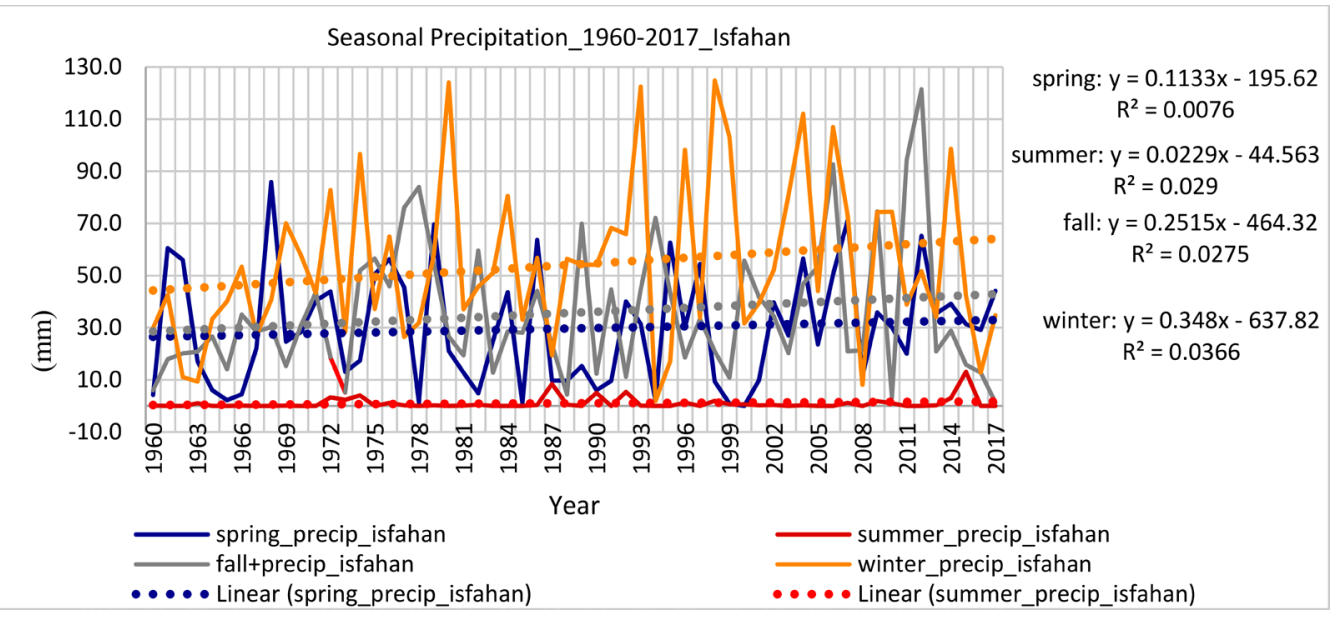

Figure 11. Seasonal mean precipitation changes in Isfahan (1960-2017).

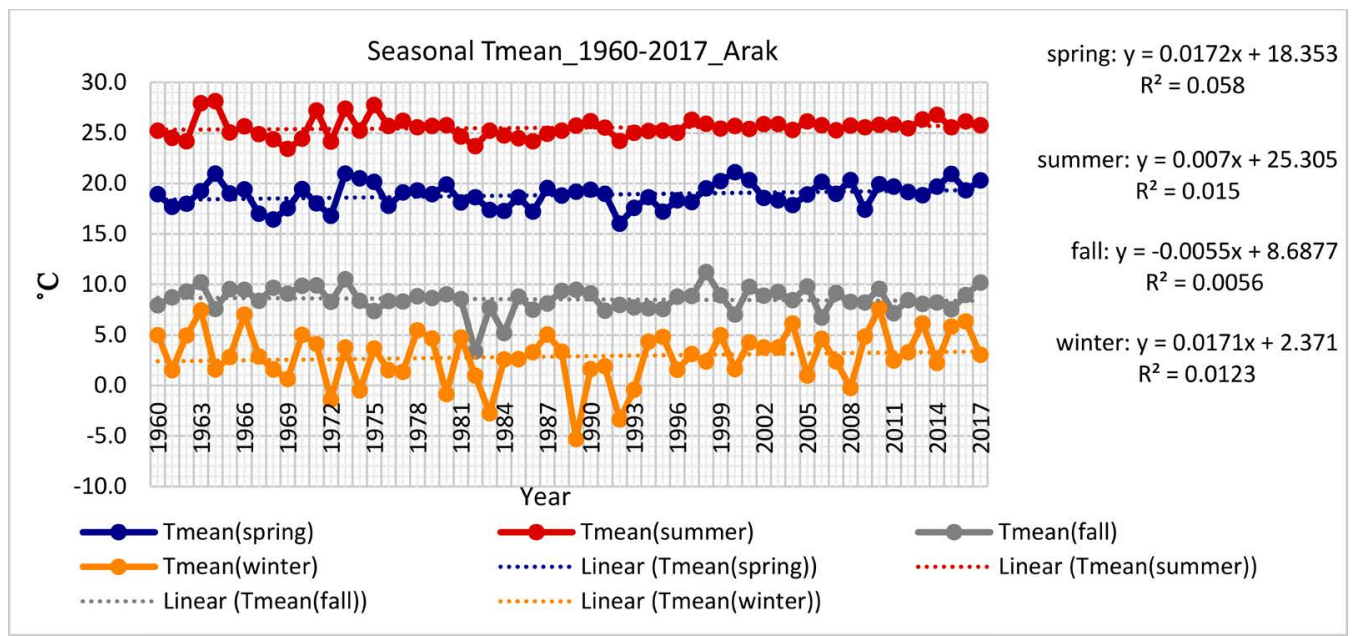

Figure 12. Seasonal mean temperature changes in Arak (1960-2017).

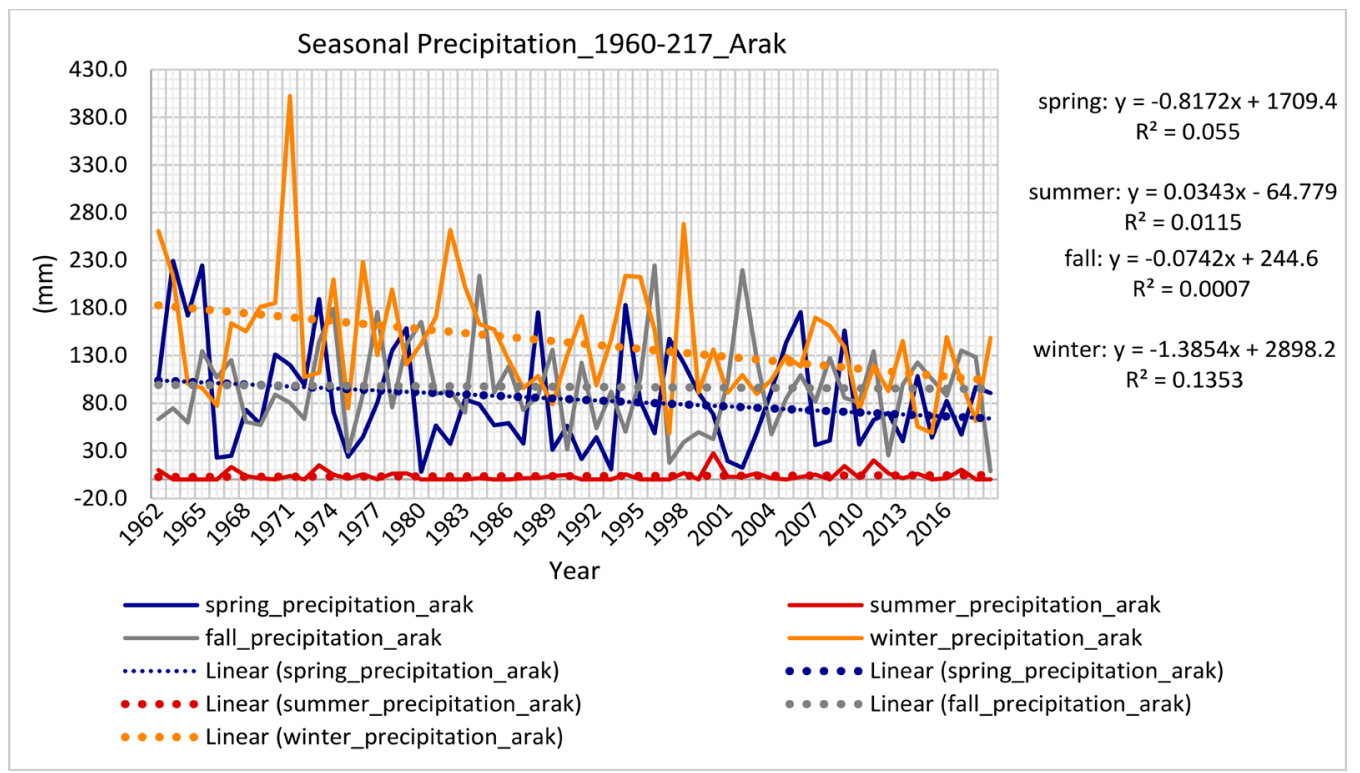

Figure 13. Seasonal mean precipitation changes in Arak (1960-2017). 


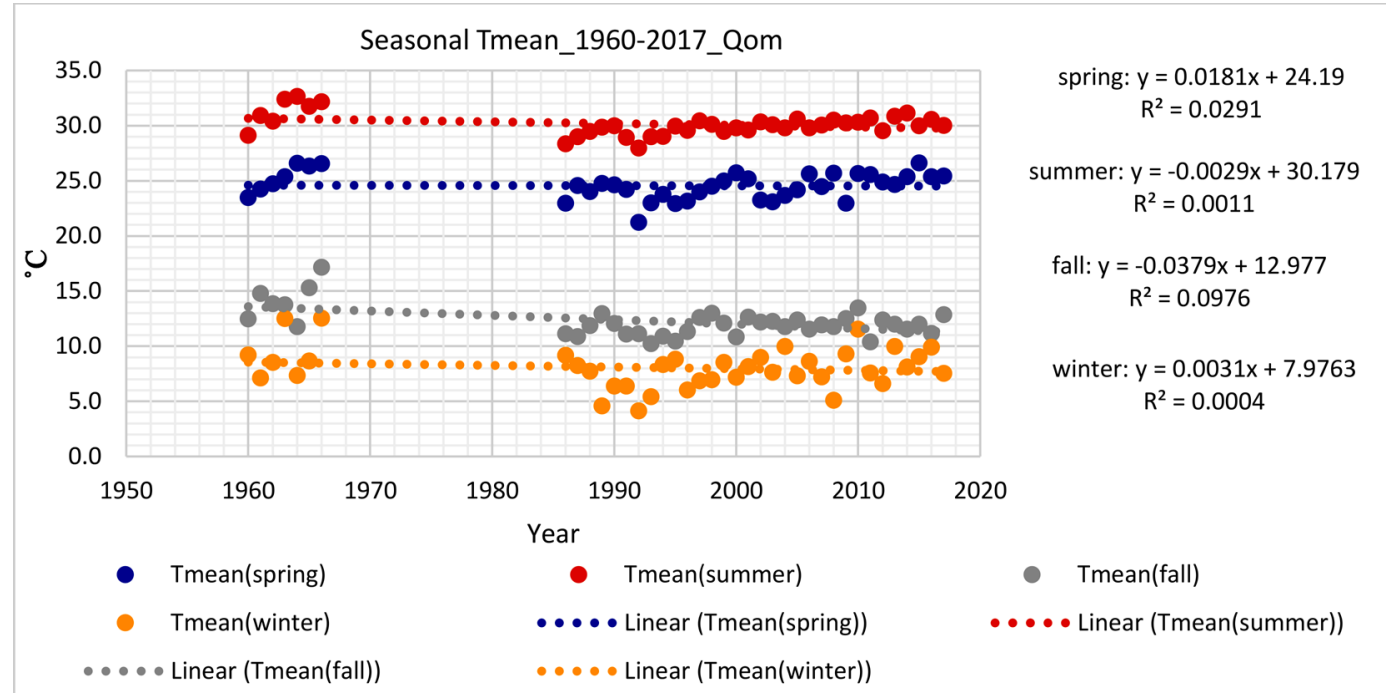

Figure 14. Seasonal mean temperature changes in Qom (1960-2017).

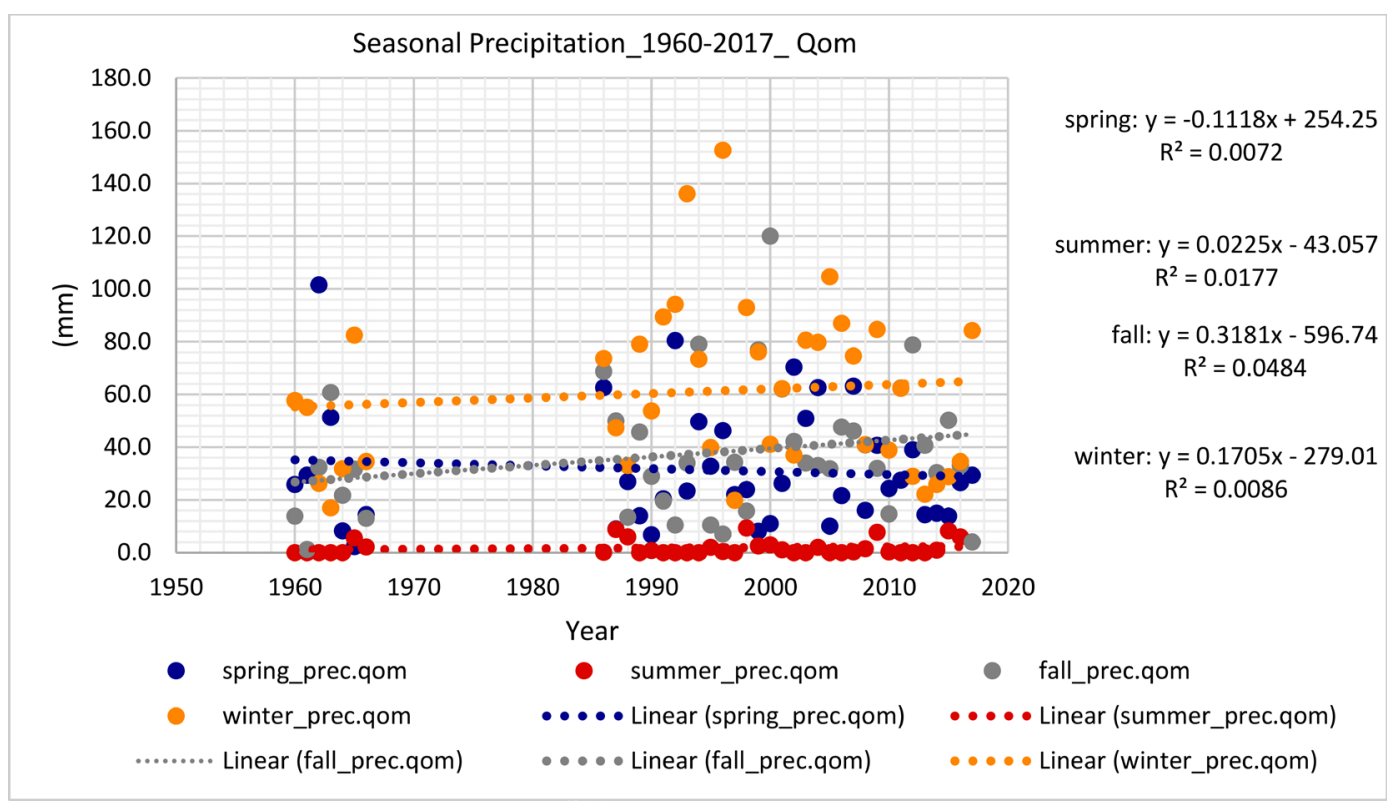

Figure 15. Seasonal mean precipitation changes in Qom (1960-2017).

\section{Seasonal Trends in Temperatures and Precipitation Interpretation}

Here, we explain the trends of mean, maximum and minimum temperature parameters and seasonal precipitation for these five selected cities as follows:

Tehran:

As it is shown in Figure 6, the trend of mean temperature changes over the period 1960-2017 is ascending and X coefficients are positive for all four seasons. Considering the $\mathrm{R}^{2}$ values as well as the critical values for the correlation coefficient $r$, the mean temperature for all seasons is significant at a probability of $99 \%$ with $0.01 \%$ level of significance. The maximum temperature is only significant at a level of $0.01 \%$ in spring. Whereas at a level of $0.05 \%$, except during spring and 
winter seasons are not significant even at the $0.05 \%$ level. The minimum temperature in all seasons is significant at both levels with an increasing trend. The precipitation due to the very small correlation coefficient is not at any significant level and therefore it cannot be discussed (Figure 7). The ratios of mean, maximum, minimum temperatures and mean precipitation coefficients for four seasons according to the statistical regression relation for a decade (by 10 times of the coefficient $\mathrm{x}$ in each relationship) with respect of the positive (negative) sign for increase (decrease) frequency over a decade also are obtained. All quantities are listed in Tables 4-7.

\section{Semnan:}

Based on Figure 8, the mean temperature in the main range (1960-2017) is only at a level of $0.05 \%$ for the fall season significant with an increasing trend. The maximum temperature is only significant at $0.05 \%$ in spring and shows an increasing trend. The minimum temperature is significant at a level of $0.01 \%$ and shows an increasing trend. But at a level of $0.05 \%$, in addition to these two seasons, during winter also there is a meaningful increasing trend at $0.05 \%$. The trend of precipitation changes is not significant in all four seasons (Figure 9).

Isfahan:

According to Figure 10, the increase in mean temperature trend is significant at a level of $0.01 \%$ for the long-term during spring, summer, and fall seasons. Maximum temperature with a probability of $99 \%$ (at a significant level of $0.05 \%$ ) for all seasons except winter and shows an increasing trend and minimum temperature for spring at level of $0.05 \%$ and for fall at level of 0.01 shows an increasing trend. The trend of precipitation changes is also not significant in all four seasons (Figure 11).

Arak:

As it is shown in Figure 12, the mean temperature at any level in all four seasons is not significant for long interval period (1960-2017). The minimum temperature is not significant at any level. Precipitation also shows a significant decrease at a level of $0.01 \%$ only in winter with a decreasing trend (Figure 13).

Qom:

As it is shown in Figure 14, the mean temperature trend over the long term (1960-2017) for the fall season is significant at the $0.05 \%$ level. The maximum temperature trend for all seasons, except autumn (is not significant), is significant and with an increasing trend at $0.01 \%$ level. The minimum temperature is only significant at $0.01 \%$ in summer with an increasing trend. But at $0.05 \%$ level, the minimum temperature is significant during summer and shows a decreasing trend during other seasons. Precipitation parameters at this station could not be analysed at any significant levels (Figure 15).

The seasonal quantitative changes in the coefficients for mean, maximum, minimum temperatures and mean precipitation for selected stations in the central Iran provinces over a decade are brought in Tables 4-7. The negative sign means the reduction of the parameter. Also, Table 8 shows the seasonal trends 
Table 4. Linear trend coefficients for mean, maximum, minimum and precipitation, spring (1960-2017).

\begin{tabular}{ccccc}
\hline Station & $\begin{array}{c}\text { Spring mean } \\
\text { temperature } \\
\left({ }^{\circ} \mathrm{C} / \text { decade }\right)\end{array}$ & $\begin{array}{c}\text { Spring maximum } \\
\text { temperature } \\
\left({ }^{\circ} \mathrm{C} / \text { decade }\right)\end{array}$ & $\begin{array}{c}\text { Spring minimum } \\
\text { temperature in } \\
\text { spring }\left({ }^{\circ} \mathrm{C} / \text { decade }\right)\end{array}$ & $\begin{array}{c}\text { Spring rainfall } \\
(\mathrm{mm} / \text { decade })\end{array}$ \\
\hline Tehran & 0.45 & 0.25 & 0.65 & -1.1 \\
Semnan & 0.08 & 0.23 & 0.55 & -0.6 \\
Isfahan & 0.4 & 0.4 & 0.3 & 1.1 \\
Arak & 0.1 & 0.11 & -0.04 & -7 \\
Qom & 0.18 & 0.44 & -0.04 & -2 \\
\hline
\end{tabular}

Table 5. Linear trend coefficients for mean, maximum, minimum and precipitation, summer (1960-2017).

\begin{tabular}{ccccc}
\hline station & $\begin{array}{c}\text { Summer mean } \\
\text { temperature } \\
\left({ }^{\circ} \mathrm{C} / \text { decade }\right)\end{array}$ & $\begin{array}{c}\text { Summer maximum } \\
\text { temperature } \\
\left({ }^{\circ} \mathrm{C} / \text { decade }\right)\end{array}$ & $\begin{array}{c}\text { Summer minimum } \\
\text { temperature } \\
\left({ }^{\circ} \mathrm{C} / \text { decade }\right)\end{array}$ & $\begin{array}{c}\text { Summer rainfall } \\
(\mathrm{mm} / \text { decade })\end{array}$ \\
\hline Tehran & 0.3 & 0.1 & 0.41 & 0.39 \\
Semnan & -0.09 & 0.08 & 0.42 & 1.6 \\
Isfahan & 0.2 & 0.2 & 0.08 & 0.22 \\
Arak & 0.07 & 0.02 & 0.12 & -9 \\
Qom & -0.2 & 0.28 & 0.3 & 0.27 \\
\hline
\end{tabular}

Table 6. Linear trend coefficients for mean, maximum, minimum and precipitation, fall (1960-2017).

\begin{tabular}{ccccc}
\hline Station & $\begin{array}{c}\text { Fall mean } \\
\text { temperature } \\
\left({ }^{\circ} \mathrm{C} / \text { decade }\right)\end{array}$ & $\begin{array}{c}\text { Fall maximum } \\
\text { temperature } \\
\left({ }^{\circ} \mathrm{C} / \text { decade }\right)\end{array}$ & $\begin{array}{c}\text { Fall minimum } \\
\text { Temperature } \\
\left({ }^{\circ} \mathrm{C} / \text { decade }\right)\end{array}$ & $\begin{array}{c}\text { Fall rainfall } \\
(\mathrm{mm} / \text { decade })\end{array}$ \\
\hline Tehran & 0.65 & 0.1 & 0.67 & 3.2 \\
Semnan & 0.55 & -0.08 & 0.14 & 0.01 \\
Isfahan & 0.3 & 0.3 & 0.14 & 2.5 \\
Arak & 0.11 & 0.14 & -0.064 & -0.07 \\
Qom & -0.04 & 0.13 & -0.03 & 3.7 \\
\hline
\end{tabular}

Table 7. Linear tend coefficients for mean, maximum, minimum and precipitation, winter (1960-2017).

\begin{tabular}{ccccc}
\hline Station & $\begin{array}{c}\text { Winter mean } \\
\text { temperature } \\
\left({ }^{\circ} \mathrm{C} / \text { decade }\right)\end{array}$ & $\begin{array}{c}\text { Winter maximum } \\
\text { temperature } \\
\left({ }^{\circ} \mathrm{C} / \text { decade }\right)\end{array}$ & $\begin{array}{c}\text { Winter minimum } \\
\text { Temperature } \\
\left({ }^{\circ} \mathrm{C} / \text { decade }\right)\end{array}$ & $\begin{array}{c}\text { Winter rainfall } \\
(\mathrm{mm} / \text { decade })\end{array}$ \\
\hline Tehran & 0.53 & 0.31 & 0.51 & -1.1 \\
Semnan & 0.099 & 0.24 & 0.33 & -1.9 \\
Isfahan & 0.2 & 0.3 & 0.09 & 3.4 \\
Arak & 0.17 & 0.36 & 0.17 & -13.8 \\
Qom & 0.03 & 0.44 & -0.4 & -0.84 \\
\hline
\end{tabular}


Table 8. Seasonal trends and significant probabilities (\%) for mean temperatures (1960-2017).

\begin{tabular}{ccccc}
\hline Station & Spring & Summer & Fall & Winter \\
\hline Tehran & Increasing (99\%) & Increasing (99\%) & Increasing (99\%) & Increasing (99\%) \\
Semnan & No meaning & No meaning & Decreasing (95\%) & No meaning \\
Isfahan & Increasing (99\%) & Increasing (99\%) & Increasing (99\%) & Decreasing (95\%) \\
Arak & No meaning & No meaning & No meaning & No meaning \\
Qom & No meaning & No meaning & Increasing (95\%) & No meaning \\
\hline
\end{tabular}

and significant probabilities (\%) for mean temperatures for selected stations during 1960-2017.

\section{Summary and Conclusion}

In this research, we investigated the long term (1960-2017) seasonal mean temperature changes for five selected stations for central provinces of Iran which are in drought risk. The slight changes in the coefficients of maximum, minimum and seasonal temperature coefficients were concluded. For seasonal precipitation, according to the statistical analysis of the results, it was indicated that this parameter was not significantly correlated at any level during the main statistical period. However, the general pattern of the long-term precipitation calculations for a decade showed the decreasing trend form. From the point of view of the drought severity classification using Palmer index, we can observe the most severe drought intensity in selected stations in Arak, Qom, Semnan, Tehran and Isfahan respectively in all four seasons, especially in summer and autumn during the period of 1960-2005. Thus, the increase in temperature in the central selected stations in Iran, as well as the decrease in precipitation, is clear from the effects of the intensification of changes in climate variables. According to these results, the highest maximum (minimum) temperature rise has been calculated for Qom (Tehran) station during spring and winter (fall) seasons $\sim 0.44^{\circ} \mathrm{C}\left(\sim 0.67^{\circ} \mathrm{C}\right)$ in a decade in the period of 1960-2017. However, the highest decrease in precipitation in winter has been calculated $\sim 13.8 \mathrm{~mm}$ in a decade in the period 1960-2017 for Arak station.

\section{Acknowledgements}

The authors would like to acknowledge Iran Meteorological Organization for providing meteorological data and thanks to NOAA/ESRL PSD, Physical Science Division, Boulder Colorado web page through http://www.esrl.noaa.gov/psd/. Also special thanks to Mr Asgari for useful comments.

\section{Conflicts of Interest}

The authors declare no conflicts of interest regarding the publication of this paper. 


\section{References}

Ansari, H., Davari, K., \& Sanaeinezhad, S. H. (2010). Drought Monitoring with New Precipitation and Evapotranspiration Index on Fuzzy Logic. Journal of Water and Soil, 24, 38-52.

Bayissa, Y., Maskey, S., Tadesse, T., Van Andel, S., Moges, S., Van Griensven, A., \& Solomatine, D. (2018). Comparison of the Performance of Six Drought Indices in Characterizing Historical Drought for the Upper Blue Nile Basin, Ethiopia. Geosciences, 8, 81. https://doi.org/10.3390/geosciences8030081

Brunetti, M., Maugeri, M., Nammi, T., Navarra, A., Mauger, M., Nanni, T., \& Navarra, A. (2002). Droughts and Extreme Events in Regional Daily Italian Precipitation Series. International Journal of Climatology, 22, 509-621. https://doi.org/10.1002/joc.751

CCSP (2008). The Effects of Climate Change on Agriculture, Land Resources, Water Resources, and Biodiversity in the United States. A Report by the U.S. Climate Change Science Program and the Subcommittee on Global Change Research, Washington DC: U.S. Environmental Protection Agency.

Gibbs, W. J., \& Maher, J. V. (1967). Rainfall. Deciles as Drought Indicators, Bureau of Meteorology Bulletin No. 4, Melbourne: Commonwealth of Australia.

Hayes, M. J., Svoboda, M. D., Wilhite, D. A., \& Vanyarkho, O. V. (1999). Monitoring the 1996 Drought Using the Standardized Precipitation Index (p. 31). Drought Mitigation Center Faculty Publications. https://doi.org/10.1175/1520-0477(1999)080<0429:MTDUTS >2.0.CO;2

Hejazi Zadeh, Z., Nasserzadeh, M. H., Hatemif, D., \& Rezaei, M. (2014). Application of Statistical Methods and Drought Profiles in Analyzing Precipitation Fluctuations. Case Study: Kerman Station. Geographic Study of Arid Regions. Issue 17 Autumn. (In Farsi)

Institute of Meteorology (2008). Report on Drought Status Analysis of North Khorasan Using Meteorological Drought Indicators. (In Farsi)

Institute of Meteorology (2010). Report on Agricultural Drought Assessment and Forecasting Plan. (In Farsi)

Settele, J., Scholes, R., Betts, R., Bunn, S., Leadley, P., Nepstad, D., Overpeck, J. T., \& Taboada, M. A. (2014). Terrestrial and Inland Water Systems. In C. B. Field, V. R. Barros, D. J. Dokken, K. J. Mach, M. D. Mas-trandrea, T. E. Bilir, M. Chatterjee, K. L. Ebi, Y. O. Estrada, R. C. Genova, B. Girma, E. S. Kissel, A. N. Levy, S. MacCracken, P. R. Mastrandrea, \& L. L. White (Eds.), Climate Change 2014: Impacts, Adaptation and Vulnerability. Part A: Global and Sectoral Aspects. Contribution of Working Group II to the Fourth Assessment Report of the Intergovernmental Panel on Climate Change (271-359). Cambridge, United Kingdom and New York: Cambridge University Press.

Kalnay, E., Kanamitsu, M., Kistler, R., Collins, W., Deaven, D., Gandin, L., Joseph, D. et al. (1996). The NCEP/NCAR 40-Year Reanalysis Project. Bulletin of the American Meteorological Society, 77, 437-471. https://doi.org/10.1175/1520-0477(1996)077<0437:TNYRP >2.0.CO;2

Kebat, P., Schulze, R. E., Hellmuth, M. E., \& Veraart, J. A. (2002). Coping with Impacts of Climate Variability and Climate Change in Water Management: A Scoping Paper (114 p.). Wageningen: International Secretariat of the Dialogue on Water and Climate.

Lawrimore, J. et al. (2002). Beginning a New Era of Drought Monitoring across North America. Bulletin of the American Meteorological Society, 83, 1191-1192. https://doi.org/10.1175/1520-0477(2002)083<1191:BANEOD>2.3.CO;2

Li, Y. P., Ye, W., Wang, M., \& Yan, X. (2009). Climate Change and Drought: A Risk Assessment of Crop-Yield Impacts. Climate Research, 39, 31-46.

https://doi.org/10.3354/cr00797 
McKee, T. B., Doesken, N. J., \& Kleist, J. (1995). Drought Monitoring with Multiple Time Scales. In Proceedings of the Ninth Conference on Applied Climatology (pp. 233-236). Dallas, TX: American Meteorological Society.

Mondol, M. A., Ara, I., \& Das, S. C. (2016). Drought Index Mapping in Bangladesh by Using Standardized Precipitation Index (SPI) over 1991-2010.

Palmer, W. C. (1965). Meteorological Drought. Office of Climatology Research Paper No. 45, Washington DC: US Weather Bureau.

Sanainejad, S. H., Ansari, H., Davari, K., \& Morid, S. (2003). Monitoring and Assessment of Drought Severity in Mashhad at Different Time Scales Using Standardized Precipitation Index (SPI). Journal of Water and Soil, 17, 201-209.

Sayari, N., Bannayan, M., Alizadeh, A., \& Farid, A. (2012). Using Drought Indices to Assess Climate Change Impacts on Drought Conditions in the Northeast of Iran (Case Study: Kashafrood Basin). Meteorological Applications, 20, 115-127.

https://doi.org/10.1002/met.1347

Smith, J. B., Huq, S., Lenhart, S., Mata, L. J., Nemesova, I., \& Toure, S. (1996). Vulnerability and Adaptation to Climate Change: Interim Results from the U.S. Country Studies Program (366 p). Dordrecht, Boston, MA, London: Kluwer Academic Publication.

Smith, K. (2000). Environmental Hazards: Assessing Risk and Reducing Disaster (3rd ed.). London and New York: Routledge, Taylor and Francis Group.

Spinoni, J., Gustavo Naumann, G., Hugo Carrao, H., Paulo Barbosa, P., \& Jurgen Vogt, J. (2014). World Drought Frequency, Duration, and Severity for 1951-2010. International Journal of Climatology, 34, 2792-2804. https://doi.org/10.1002/joc.3875

Watson, R. T., Zinyowera, M. C., \& Moss, R. H. (1997). The Regional Impacts of Climate Change: An Assessment of Vulnerability (517 p.). A Special Report of IPCC Working Group II, Cambridge: Cambridge University Press.

WMO World Meteorological Organization (2015). Guidelines on the Definition and Monitoring of Extreme Weather and Climate Events. 